\title{
Wholesale Drug Distributor
}

National Cancer Institute

\section{Source}

National Cancer Institute. Wholesale Drug Distributor. NCI Thesaurus. Code C118411.

An individual or business licensed to distribute drugs in the state where business is conducted. 